\title{
Review: \\ Current status of ethnobiological studies in Merauke, Papua, Indonesia: A perspective of biological-cultural diversity conservation
}

\author{
MAIKEL SIMBIAK ${ }^{1}$, JATNA SUPRIATNA ${ }^{1, \bullet}$, EKO BAROTO WALUJO ${ }^{2}$, NISYAWATI ${ }^{1}$ \\ ${ }^{1}$ Conservation Biology Program, Department of Biology, Faculty of Mathematics and Natural Sciences, Universitas Indonesia. Depok 16424, West Java, \\ Indonesia. Tel.: +62-21-7270163, Fax.: +62-21-78829010, `email: jsupriatna@ sci.ui.ac.id \\ ${ }^{2}$ Indonesia National Museum of Natural History, Indonesian Institute of Sciences. Bogor 16122, West Java, Indonesia
}

Manuscript received: 12 October 2019. Revision accepted: 1 November 2019.

\begin{abstract}
Simbiak M, Supriatna J, Walujo EB, Nisyawati. 2019. Review: Current status of ethnobiological studies in Merauke, Papua, Indonesia: A perspective of biological-cultural diversity conservation. Biodiversitas 20: 3455-3466. Ethnobiology is a scientific study that examines the dynamic relationship between humans, biota and the environment. In this dynamic relationship, holistic notions that integrate humans and their cultural and biological diversity give more responsibility to ethnobiological studies. This research approach stimulates insights to integrate scientific research with awareness of political and ecological issues, loss of biological resources, including indigenous peoples' struggles over land and resources, identity degradation due to loss of culture and language. Ethnobiological studies undertaken in Merauke, Papua between 2000 and 2017 were reviewed from the perspective of biologicalcultural diversity conservation. The aims and results of such published ethnobiological studies were analyzed and we found the failure of such studies in accounting for linguistic diversity in the region while documenting ethnobiological knowledge. Most of such ethnobiological studies were oriented on the topic of economic botany, focusing on recording the potential uses of plants utilized by each ethnic group in the Marind language-culture area of Merauke District, especially those belonging to the domain of medicinal plants. Some studies also used artificial community terminology to treat several ethnic groups as uniform and did not mention what language used for the local names of plants in their reports. Future ethnobiological research in the area would benefit from: (i) adopting a cognitive ethnobiology orientation; (ii) applying appropriate ethnolinguistics standards of research to document the languages; and (iii) using a quantitative approach to analyze the distribution of ethnobiological knowledge within the communities studied. The latter approach is especially important given the extreme and rapid changes of the environment in this region.
\end{abstract}

Keywords: Biocultural conservation, ethnobiology, Kolopom-Marind language-culture area, Merauke, Southern New Guinea

\section{INTRODUCTION}

The Society of Ethnobiology defines ethnobiology as the scientific study of the dynamic relationship between humans, biotas, and environments (Wolverton 2013). The field of ethnobiology has become a bridge for documenting various aspects of human knowledge in relation to the biophysical environment (Lepofsky 2009; Anderson et al. 2011; Albuquerque et al. 2014). The ecological knowledge and beliefs of indigenous peoples and the ways they attempt to preserve their inherited environment from generation to generation are vitally important to the cultural traditions of indigenous and rural communities around the world (Menzies and Butler 2006; Negi 2010). Indigenous peoples' knowledge about the nature of their environment is formed through a series of progressive cognitive adaptations and produces an inseparable relationship with their cultural landscape (Woldeamanuel 2012; Bergamini et al. 2013; Sutton and Anderson 2014; Plieninger et al. 2018). These communities do not want to lose traditional knowledge, especially when they need to manage key resources and ecosystems.

Conducting and publishing ethnobiological research has become an important way of preserving knowledge about medicine, food crops, farming techniques, conservation and management, and much more (Anderson 2011). However, accessing ethnobiological information can be difficult, because it tends to be scattered across publications in various scientific fields, each of which adopts slightly different terminologies (Wolverton 2013; D'Ambrosio 2014). This is the nature of a growing discipline to find its definition and orientation, research methods, and relationships with other scientific fields that overlap with questions and areas of interest because of the fusion of researchers with various theoretical and epistemological backgrounds (Albuquerque and Medeiros 2013; Albuquerque et al. 2015). However, the insights provided by ethnobiologist (e.g., Martin 2001; Anderson 2010; Wolverton 2013) indicate that there is a great desire to create ethnobiology as an interdisciplinary field which is the scientific umbrella for a number of scientific disciplines related to the relations among people, biota, and environment in various angle of studies.

Ethnobiology has been practiced since the dawn of human civilization but is relatively new as a discipline (Martin 2001). As a discipline Clement (1998) classified the historical development of ethnobiology in three eras, pre-classical, classical, and post-classical. Martin (2001) 
stated that this historical study provides an appropriate basis for considering current trends in basic and applied studies of ethnobiology. Hunn (2007) extends the history of ethnobiology development into four phases. Phase 1, first step (1895-1950)-ethnobotany and ethnobiology were formally introduced academically and ethnobiology studies at this phase focusing on the documentation of useful plants and animals. Phase 2, cognitive ethnobiology or ethnoscience (1954-1970s)-the cognitive ethnobiology studies with strong links to psychology and linguistics dominate various ethnobiological studies. Phase 3, ethnoecology (1970s-1980s)-the recognition of ecological knowledge system of indigenous peoples became the spirit of ethnobiological studies. Phase 4, indigenous ethnobiology (the 1990s)-ethnobiology was lifted from the practice of 'exploitation' of indigenous peoples' knowledge and resources through various initiatives to provide broader space in the involvement of indigenous peoples. One important development in this phase is the increasing biocultural concept in ethnobiological studies (Hidayati et al. 2015) promoted by Luisa Maffi and many researchers (Pretty et al. 2009; Cocks 2010; Maffi and Woodley 2010; Sterling et al. 2010; Wyndham et al. 2011; Arts et al. 2012; Davidson-Hunt et al. 2012; Hong 2014; Agnoletti and Rotherham 2015; Buizer et al. 2016). Furthermore, Hunn's four phases become the foundation of the fifth phase (phase 5 ) of the ethnobiology in which ethnobiologist are encouraged to have capability and responsibility by taking a more significant role in facing the ecological and humanitarian crises in the 21 st century and global changes in the economy and ethnobiology knowledge systems (Wyndham et al. 2011; Wolverton 2013).

The spirit of phase 5 is an appropriate approach to be implemented in ethnobiological studies in Indonesia which is rich in biological, cultural and linguistic diversity (Harmon 1996; Maffi 2001; Loh and Harmon 2005; Gorenflo et al. 2012), yet ethnobiology studies have not well-developed in this country (Walujo 2008; and Hidayati 2015). Although the field of ethnobiology has developed sluggishly in Indonesia, the wide variety of ethnicities and cultures encompassed by this archipelago nation present many opportunities for research (Walujo 2008) especially in Western New Guinea (Tanah Papua).

Tanah Papua is part of New Guinea that is politically part of Indonesia. New Guinea is a fantastic island, unique and fascinating. It is an area with incredible variety of geomorphology, biota, peoples, languages, history, traditions and cultures. Diversity is its prime characteristic, whatever the subject of interest (Gressit 1982). Yet, ethnobiological studies in Tanah Papua have yet to reflect this diversity. This paper reviews ethnobiological studies conducted between 2000 and 2017 in Merauke District, Papua Province, Indonesia and is aimed in part to integrate ethnobiological research scattered across many fields and publications. Since language is the most important cultural tool for transmitting and preserving all aspects of traditional knowledge, the current authors also reflect on language issues in examining the status of ethnobiological research in Merauke District and develop suggestions for future research.

\section{BIOCULTURAL DIVERSITY CONSERVATION: A BRIEF OVERVIEW}

The concept of biocultural diversity, which refers to the interconnection between biological diversity and cultural diversity (Pretty et al. 2009), emerged approximately one decade after the term "biological diversity" appeared in the 1968 book titled A Different Kind of Country by scientist and conservationist Raymond F. Dasmann. According to Article 2 of the Convention on Biological Diversity (CBD), biological diversity is defined as follows:

The variability among living organisms from all sources including, inter alia, terrestrial, marine, and other aquatic ecosystems, and the ecological complexes of which they are part; this includes diversity within species, between species, and of ecosystems (CBD 2019)

In 1980, this term became a part of the scientific jargon when Thomas E. Lovejoy promoted the concept in order to remind the scientific community about the negative impact of human activities on Earth's biological systems (Franco 2013). In September 1986, this concept was reintroduced as "biodiversity" by Walter G. Rosen at the National Forum on Bio Diversity in Washington, D.C., where selected papers were eventually published in the 1988 book titled Biodiversity by Edward O. Wilson (editor) (Wilson 1988; Lousley 2012). Thus, the 1980s can be considered as the decade in which the term "biodiversity" helped draw attention to the crisis in which the diversity of life in nature was being constantly threatened by humans (Maffi 2005).

In the late $1980 \mathrm{~s}$, a new awareness emerged in which the erosion of biological diversity became interconnected with the disruption and destruction of the culture of indigenous peoples around the world, which resulted in the Declaration of Belem at the First International Congress of Ethnobiology in 1988 (Posey and Dutfield 1996). Although the idea of a biocultural system actually emerged at the UNESCO World Heritage Convention in 1972, which aimed to unite the research on socio-ecological systems and human-centered cultural landscapes (Bridgewater and Rotherham 2019), it was subsequently incorporated into the CBD's international conservation policy in 1992, which formally stated the need to recognize the value of biodiversity for indigenous peoples and local communities (Cocks and Wiersum 2014). Therefore, the late 1980s to the early 1990s might be considered as the time period in which the concept of an intimate relationship among biological, cultural, and linguistic diversities was put forward, along with its implications for life in nature and culture (Maffi 2005).

The idea of bridging the concept of biological diversity and cultural diversity in an integrative manner has been discussed in several studies. For example, Harmon (1996), Loh and Harmon (2005), and Stepp et al. (2004, 2005) showed the co-occurrence between biological richness and language richness as a representation of cultural elements. More recent studies indicated that such co-occurrence is still a central issue in global nature conservation (e.g., Gorenflo 2012; Hidayati 2015; Skutnabb-Kangas and Harmon 2015; Brundu et al. 2017; Upadhyay and Hasnain 2017). 
Since it is conceptually rooted in different disciplines (e.g., natural science and social science), which has produced various difficulties in collaborative interdisciplinary efforts (Cocks 2010), biocultural diversity has been the subject of numerous discussions regarding its actual definition (Bridgewater and Rotherham 2019). First, the initial concept of biocultural diversity based on cartography, which highlighted the centers of wildlife, was criticized for considering a broader and dynamic perspective of the role of humans in relation to biological and cultural diversity (Brosius and Hitchner 2010). In this regard, Maffi (2005) provided a conceptual framework by defining biocultural diversity as "the diversity of life in all its manifestations - biological, cultural, and linguisticwhich are interrelated within a complex socio-ecological adaptive system." Considering that the earlier definition was too broad, Harmon and Loh (2010) synthesized a more detailed definition:

Biocultural diversity is the total variety exhibited by the world's natural and cultural systems. It may be thought of as the sum total of the world's differences, no matter what their origin. It includes biological diversity at all its levels, from genes to populations to species to ecosystems; cultural diversity in all its manifestations (including linguistic diversity), ranging from individual ideas to entire cultures, the abiotic or geophysical diversity of the Earth, including that of its landforms and geological processes, meteorology, and all other inorganic components and processes (e.g., chemical regimes) that provide the setting for life; and, importantly, the interactions among all of these.

At its 2018 conference on "Nature and Culture" in Egypt, the CBD produced two terms related to biocultural concepts, with their respective definitions: (i) biocultural diversity, which is "considered as biological diversity and cultural diversity, and the links between them," and (ii) biocultural heritage, which reflects "the holistic approach of many indigenous peoples and local communities." The cultural landscape inscribed under the aforementioned World Heritage Convention is an example of biocultural heritage. This holistic and collective conceptual approach also recognizes knowledge as "heritage," thereby reflecting its custodial and intergenerational character. Overall, both definitions elucidate the biocultural concept from a global diversity perspective and a cultural landscape perspective, respectively.

While the debate regarding biocultural concepts and biocultural diversity is ongoing, theoretical and empirical studies on the dynamic relationship among biological, cultural, and linguistic diversities are still being conducted. From the theoretical perspective, several studies have focused on basic principles and approaches, including policy directions that can be implemented in conservation programs through an integrated biocultural approach (e.g., Sterling et al. 2010; Hill et al. 2011; Carroll et al. 2017; Davidson-Hunt et al. 2012; Grant 2012; Swiderska 2013; Hong 2014; Poe et al. 2014; Gavin et al. 2015; Dunn 2017). Meanwhile, other researchers have explored human creativity in natural and cultural hybrid systems, including the incorporation of biodiversity in the human domain through human landscape modification and agrobiodiversity (e.g., Rahu et al. 2013; Cocks and Wiersum 2014; Temudo et al. 2014; Agnoletti et al. 2015; Agnoletti and Rotherham 2015; Molnar et al. 2015; Ekblom et al. 2018; Mastretta-Yanes et al. 2018).

From the empirical perspective, several studies have examined human-nature relations by including indigenous peoples and their perspectives (both local and global) on environmental conservation (e.g., Yaofeng et al. 2009; Dudley 2010; Robson and Berkes 2010; Cocks et al. 2012; Mukul et al. 2012; Ormsby 2012; Hong et al. 2014; Frascaroli and Verschuuren 2016; Jupiter 2017; Singh et al. 2017; Morishige et al. 2018; Murray and Agyare 2018; Singh et al. 2019). Meanwhile, other researchers have focused on various issues related to ecologically sustainable development (Paolisso and Dery 2010; TEEB 2010; Laird et al. 2011; Bogaert et al. 2014; Liu et al 2014; Sukhdev et al. 2014; Lyver et al. 2015; Bremer et al. 2018; Lyver et al. 2018; Santika et al. 2019).

Efforts to document traditional ecological knowledge systems have also received the attention of researchers, not only as a form of conservation but also as an adaptation strategy to changes in both climate and socio-ecological systems (e.g., Gyampoh and Asante 2011; Andrachuk and Armitage 2015; Budiharta et al. 2016; Makondo and Thomas 2018; Hong et al. 2018). This finding indicates that the concept of biocultural diversity is based on two fundamental considerations. First, throughout human history, people have interacted with nature (Pretty et al. 2009; Cocks and Wiersum 2014; Si and Agnihotri 2014; Bennett et al. 2017), which has produced worldviews, cosmology, and narratives that reflect the relationships among plants, animals, humans, and the supernatural (Cocks and Wiersum 2014). Second, human interactions with nature have resulted in unique cultural practices that ensure the continued existence and expression of locally respected biodiversity elements (Persic and Martin 2008; Cocks and Wiersum 2014).

As a notion promoted in the nature conservation approach, debates regarding the biocultural concept continue, both at the conceptual level (Bridgewater and Rotherham 2019) and at the economic level (Gavin et al. 2018). One fundamental issue that has sparked heated debates in nature conservation is the relationship among human culture, heritage, and nature, which is considered as ecology or biodiversity (Bridgewater and Rotherham 2019). Although many studies have revealed that nature and culture intersect at various levels, ranging from values, beliefs, and norms to practices, livelihoods, knowledge, and language (e.g., Adams 2010; Newing 2010; Tyrrel 2010; Gonzales and Gonzalez 2010; Harmon et al. 2010; Howard 2010; Agnoletti 2014; Albo 2018; Rozzi 2018), many conservation researchers and practitioners believe that a biocultural approach to conservation can produce equitable and sustainable conservation solutions (e.g., Díaz et al. 2015; Gavin et al. 2015; Caillon et al. 2017; Sterling et al. 2017; Eriksson 2018; Gavin et al. 2018; McCarter et al. 2018).

Finally, in order to emphasize the need for pluralistic, partnership-based dynamic approaches to conservation, 
Gavin et al. (2015, 2018) formulated the following eight principles: (i) acknowledge that conservation can have multiple objectives and stakeholders; (ii) recognize the importance of intergenerational planning and institutions for long-term adaptive governance; (iii) recognize that culture is a dynamic that influences resource use and conservation; (iv) tailor interventions to a socio-ecological context; (v) devise and draw upon novel, diverse, and nested institutional frameworks; (vi) prioritize the importance of partnerships and relation-building for conservation outcomes; (vii) incorporate the distinct rights and responsibilities of all parties; and (viii) respect and incorporate different worldviews and knowledge systems into conservation planning.

\section{STUDY REGION AND PROCEDURE}

The south coast of New Guinea culture extends from the Asmat tribe in the west within the territory of the Republic of Indonesia to the Elema tribe in the east within the nation of Papua New Guinea. Anthropologists have classified the ethnic groups that span the region into seven language-culture areas. Several different tribal languages are grouped into each language-culture area; each area is usually named according to the dominant language used to communicate inter-tribally within the area. The indigenous ethnic groups in Merauke District, Papua Province, Indonesia fall into two language-culture areas. The Marind language-culture group covers the plains, while the Kolopom group is located in the Yos Sudarso Island or Kolopom Island (Knauft 1993). While the dominant language in the plains region is Marind, other ethnic groups in the area speak Moraori (Marori), Kanum, Yei, Yonggom, Kaeti, Bian Marind, Meklew, and Yelmek. The Kolopom area encompasses ethnic groups speaking Kimaghama, Riantana, Ndom, and Koneraw. In Komolom Island, only single language exists on the island, Mombum. This review compares ethnobiological studies that had been conducted in the plains, that is, the Marind languageculture area, since 2000. The diversity of languages in Merauke District and its geographical distribution is shown in Figure 1. As additional information, the word "Marind" could be found in a version of "Malind" in different references (e.g. Wattimena 2013; Sofyandy 2014). Both words just show the difference of dialect between coastal and interior of Marind peoples. We also could find the phrase Suku Besar Malind (The Great Malind tribe) (e.g. Wattimena 2013; Sofyandy 2014) that use to encompass all tribes in Merauke District.

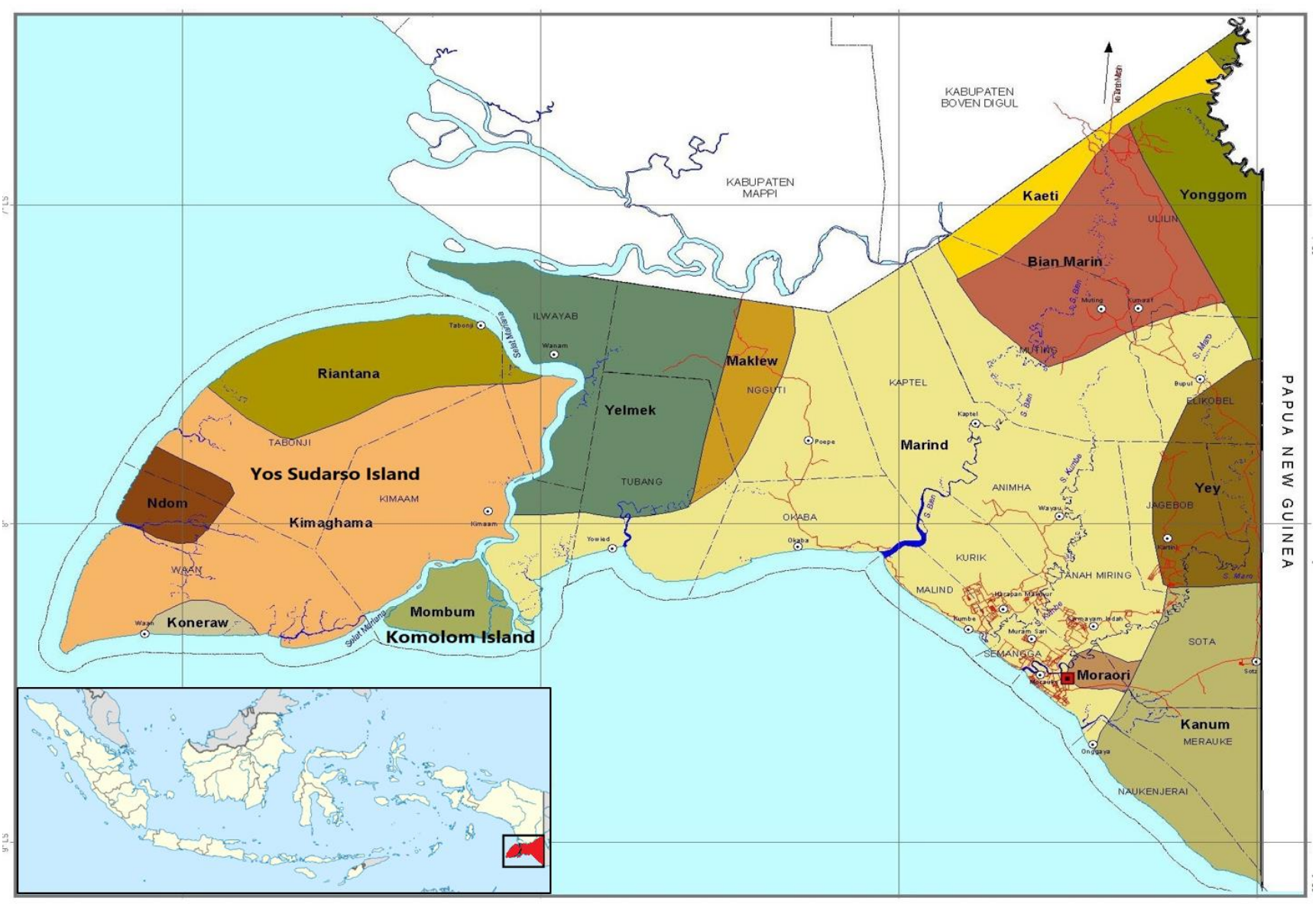

Figure 1. Indigenous languages diversity in Merauke District, Papua Province, Indonesia 
The indigenous groups comprising the Marind language-culture area share a local totemic belief system called Mayo (hence, Marind people are sometimes referred to as "Mayo Man") (Wattimena 2013). The Mayo philosophy incorporates a cosmology that shapes the perceptions of Marind tribe people as being integrated into their natural environment (Warib 1996). Totemism positions both physical and biological environments as entities that have horizontal relationships with Marind people. The Mayo totemic worldview treats animals, plants, certain places, and even humans as manifestations of Dema, a supernatural being involved in the evolution of Marind society and life histories of Marind people (Corbey 2010). This belief system is the basis for people's understanding of and customary provisions related to the utilization of resources in their natural environment (Wattimena 2013; Sofyandy 2014).

The historical dominance of the Marind tribe (henceforth, Marind anim) in this region of Papua put them in the limelight of classical ethnographic studies. The attention on the Marind anim seems to have influenced outsider understanding of all the other native groups in the area. This situation can be seen in several research reports that show the assumptions of some ethnobiologist that the "Marind" identity applies to the indigenous society in Merauke District as a whole (e.g. Haryanto et al. 2009; Wattimena 2013; Sofyandy 2014; Suharno et al. 2016). It should be understood, however, that each ethnic group (especially the tribes of Kanum, Marind, and Yei) within the Marind language-culture area speaks a different dialect or language (Van Baal 1966). A recent Summer Institute of Language (SIL) study demonstrated that each of these ethnic groups currently has difficulty understanding the languages spoken by the others (Sohn et al. 2009). The artificiality of the language-culture area designation has led ethnobiology researchers to ignore the diversity of the languages used among the indigenous tribes in Merauke District. Thus, important ethnobiological data may have been inadvertently neglected or eliminated from some studies. This problem is discussed further below.

In examining the development and tendencies of Ethnobiology in Merauke District, we analyzed papers published or research reports on this theme and focused on contemporary studies. We compiled studies concerning human-animal, human-plant, and human-land relations in Merauke that had been published in academic journals and other periodicals or included in chapters in textbooks and various reports including postgraduate theses. We used the following search keywords: ethnobiology, ethnoecology, ethnobotany, ethnozoology, ethnomedicine, biocultural, traditional knowledge, traditional ecological knowledge, traditional medicine, traditional wisdom, and socioecological. Accessing all the published studies was not possible because some journals do not provide online access, and other journals restrict content. Therefore, our survey was limited to the most recent studies published between 2000 and 2017. The search only included studies that directly investigated the relationship between human groups and different types of resources. Once all the publications were collected, they were subdivided into primarily ethnobiological, ethnobotanical, ethnozoological, or ethnoecological studies for purposes of comparison. For an academic standard, we refer to a new synthesis in the ethnobiological perspective by Martin (2001) that ethnobiology can be seen as an integrative discipline that refers to all different approaches to gathering various empirical data about the interaction between humans and biological organisms in various studies with terms such as ethnobotany, ethnozoology, and ethnoecology. By this perspective, ethnobiology combines conventional studies conducted by ethnobotanists, ethnozoologists, and ethnoscientists who present a limited vision of the interaction of local communities with the natural environment. This notion of unification is based on a central theory that the systematic knowledge of local communities, the management of organisms and biological ecosystems, can be classified as biological sciences, based on qualitative and quantitative research methods. By this narrative, ethnobotany, ethnozoology, and ethnoecology are ethnobiological sub-disciplines used as an empirical study approach to examine the dynamic relationships between human-plants, human-animals, and humanenvironment from the cultural way. This conceptual framework is analogous with the definition of ethnobiology by the Society of Ethnobiology mentioned above.

\section{ETHNOBIOLOGICAL RESEARCH IN MERAUKE}

\section{The first works}

Our search shows that studies related to ethnobiological knowledge have been conducted since the colonial era. A review of the ethnobotanical aspects of these classical studies has also been reported by Powell in the chapter "Ethnobotany" in the book "New Guinea Vegetation," edited by K. Paijmans, 1976. Powell (1976) inventoried and evaluated over 60 ethnobotany studies in New Guinea but only a small amount of the research originated from western New Guinea. These early works were criticized by Powell for not providing sufficient ethnobotany data and typically containing only local names and without clear species identification. This can happen because the early ethnobotany studies were not a major part of their work as anthropologists or geographers. From these studies only two are specifically reported from the area currently known as Merauke District, which is the study of food sources related to the nutrition of Marind people (Luyken and Luyken-Koning 1955) and Serpenti publication of 1965 on farming systems of local communities adapted to the swampy environment on Frederik-Hendrik Island (now Yos Sudarso Island) (Barrau and Scheffler 1966).

In addition to contributing to the study of ethnobotany aspects as reported by Powell (1976), some anthropologists also contributed to a wider area of ethnobiological knowledge. Some of the more accessible information is included in Kooijman's (1960) discussion of the Marind anim's (anim means man) use of a lunar calendar and Van Baal's (1966) description and cultural analysis of the Marind anim. Retracing earlier ethnographic reports, Van Baal found that plants and animals were primary subjects 
of Marind mythology. Van Baal's fairly comprehensive study thus explored human-biota relationships in the Marind anim belief system. In addition to Marind anim, Van Baal (1982) also re-analyzed Pastor Jan Verschueren's report on Yei nan (nan means man) culture that provides interesting information about food ecology of the tribe. One interesting report from the ethnographic study is the impressive land-use adaptation technology shown by indigenous peoples on the island of Kolopom for gardening on their swampy land. Yams and taro planted in man-made garden islands that reclaimed from swamps by stacking layers of clay and grass on a stretch of floating grass that has been cut. With persistent effort, they ensure the humidity level of the tolerance range of various plants that are affected by different seasonal conditions. Likewise, soil temperature and water content were always maintained, all areas cleaned regularly. Their fertilization was also very specific where the garden area coated with a thin layer of mud fertilizer, sifted with a clean sieve and then coated first with hummus and then with dry grass compost (Knauft 1993).

\section{Contemporary ethnobiological research}

Starting in the 2000s, local Indonesian and Papuan researchers began to pay more attention to ethnobiological research in the region which was started by Susiarti in 2000 (Hide 2017). Some of the more intense research has been conducted by Susiarti (2005), Kameubun (2003, 2013), and Winara and colleagues $(2015,2016)$. Actually, the contemporary ethnobiological study in this area by local Indonesian and Papuan researchers was initiated by Warib in 1993 focusing on the study of kava (Piper methysticum) in the Marind anim tradition. But the report is inaccessible and only very limited information about the local naming of kava and the knowledge of useful plants with inadequate botanical information obtained in Warib (1996). Because of its cultural value, the study of kava is then gained attention by Kameubun $(2003,2013)$ who explored in depth the knowledge of ethnic groups in Merauke about these plants including cognitive aspects related to determination and classification. Although the attention of local researchers to this field began to grow, the gap of interest in the ethnobiology study area was striking. Academics and functional researchers from research institutes are more interested in ethnobotany studies than other study areas that can be demonstrated by existing studies (Figure 2).

Existing reports also indicate that the studies that have been conducted have come from a limited geographical area and generally focus on the Wasur National Park (WNP) and its surroundings, thus involving only a limited ethnic group as well. Figure 1 shows that the indigenous peoples of Merauke District consist of various ethnic groups with their respective languages so that it is possible to have a wealth of own local wisdom. But the existing study focuses only on Kanum, Marind, and Marori tribes so there is a gap in the term of ethnic and linguistic diversity (Table 1).

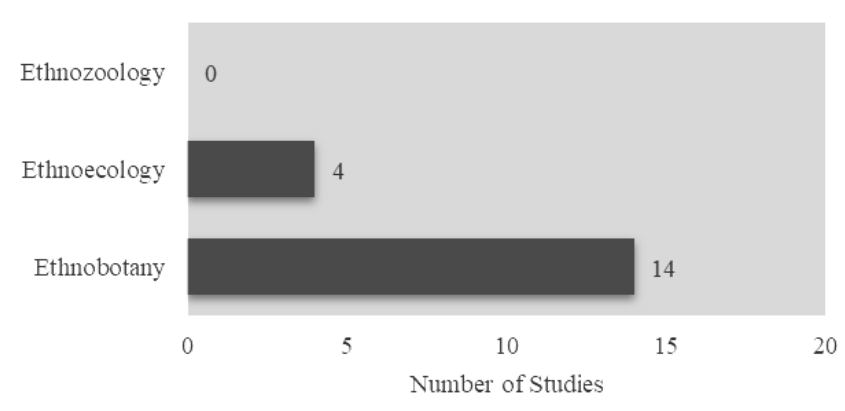

Figure 2. Distribution of contemporary ethnobiological research in Merauke District, Indonesia according to the area of study

Table 1. Distribution of contemporary research on ethnobiology field according to the existing languages in Merauke District, Papua Province, Indonesia

\begin{tabular}{|c|c|c|c|}
\hline \multirow{2}{*}{ Tribal language of geographic area } & \multicolumn{3}{|c|}{ Area of ethnobiology } \\
\hline & Ethnoecology & Ethnobotany & Ethnozoology \\
\hline \multicolumn{4}{|l|}{ Main plains } \\
\hline Bian Marind (Mbian anim) & 2 & 0 & 0 \\
\hline Kaeti & 0 & 0 & 0 \\
\hline Kanum & 2 & 10 & 0 \\
\hline Marind & 3 & 9 & 0 \\
\hline Marori & 1 & 8 & 0 \\
\hline Meklew & 0 & 0 & 0 \\
\hline Men $\mathrm{Ge}^{*}$ & 0 & 0 & 0 \\
\hline Yei & 1 & 1 & 0 \\
\hline Yelmek & 0 & 0 & 0 \\
\hline Yonggom & 0 & 0 & 0 \\
\hline \multicolumn{4}{|l|}{ Yos Sudarso Island } \\
\hline Kimaghama & 0 & 0 & 0 \\
\hline Koneraw & 0 & 0 & 0 \\
\hline Ndom & 0 & 0 & 0 \\
\hline Riantana & 0 & 0 & 0 \\
\hline \multicolumn{4}{|l|}{ Komolom Island } \\
\hline Mombum & 0 & 0 & 0 \\
\hline
\end{tabular}


Table 2. Ethnobotanical research in Merauke District, Papua Province, Indonesia

\begin{tabular}{lcl}
\hline Domain & Number of studies & References \\
\hline Medicinal plants & 7 & $\begin{array}{l}\text { Susiarti 2000 (in Hide 2017), Haryanto et al. 2009; Lobo 2012; Widya 2015; Winara } \\
\text { 2015; Suharno et al. 2016; Winara and Mukhtar 2016 }\end{array}$ \\
Useful plants & 3 & Kameubun 2003, 2013; Winara and Suhaendah 2016 \\
Food plants & 4 & Hariadi 2005; Susiarti 2005; Paay 2005; Hisa et al. 2017 \\
Dye plants & 1 & Harbelubun 2005 \\
\hline
\end{tabular}

As mentioned above that ethnobotany dominates the existing ethnobiological study in Merauke, however, almost all of these ethnobotanical studies are oriented in the topic of economic botany (Table 2). That is, researchers only reported knowledge of plant species that are of economic value to humans. The documentation of local knowledge practices in utilizing plant resources focuses primarily on the use of plants as medicine (Susiarti 2000; Haryanto et al. 2009; Lobo 2012; Widya 2015; Winara 2015; Suharno et al. 2016; Winara and Mukhtar 2016). Researchers on other ethnobotanical domains include food plants (Hariadi 2005; Paay 2005; Susiarti 2005; Hisa et al. 2017) and dye plants (Harbelubun et al. 2005). More general uses of plants in the Marori-Men Gey community at WNP were also documented by Winara and Suhaendah (2016). The results of our evaluation indicate that some of the accounts in ethnobotanical area presented repetitive information such as the study of indigenous medicinal plants of WNP has involved at least four studies, for example, Susiarti (2000), Haryanto et al. (2009), Winara (2015), and Winara and Mukhtar (2016). Similarly, in the study of kava, although Suharno et al. (2016) stated their focus on the medicinal value of kava, their discussion of cultural values contained the same study as Kameubun (2003, 2013). These findings suggest that the studies designed do not take into account the scientific rules of a study related to the novelty. Whether the aspects of the study are completely new or the development of previous studies, this is not always the case.

Various reports (e.g. Wattimena 2013; Sofyandy 2014) show that the tribes in Merauke District have a close relationship with fauna, which is characterized by Australasian fauna, but we did not find a scientific report on ethnozoological studies according to the criteria we determined. Meanwhile, some studies on the topic of ethnoecology were uncovered; all emphasize local wisdom (based on the indigenous belief system) in the management of biological and environmental resources (e.g. Kosmaryandi 2012; Muliyawan et al. 2013; Wattimena 2013; Sofyandy 2014; Wambrauw 2015). Both ethnozoological and ethnoecological studies here want to emphasize to policymakers and stakeholders that local people in this district have a strong relationship with their biophysical environment. The values contained in the relationship should be considered for development planning on the scale of its needs. Some of these concepts have been implemented such as mapping important places to maintain cultural archaeological sites of indigenous tribes. This important place concept has been applied in the zoning of Wasur National Park which places many sacred areas within the core zone of the area (Kosmaryandi 2012; Muliyawan et al. 2013) including the consideration of Spatial Planning Regulation of Merauke District (Wattimena 2013; Sulistyawan et al. 2018). Nevertheless, the studies also reveal the fact that the sustainability of local wisdom is under threat. There has been a shift in perceptions of the values of local wisdom and culture among Marind young people so that the goal of commercialization has overcome the application of customary norms in the utilization of local resources.

\section{Perspectives on future ethnobiological research in Merauke}

The above brief comparison of ethnobiological studies conducted in Merauke District suggests specific avenues for future research. The usefulness of some of these studies to future researchers is limited by the failure of a few researchers to specify the ethnic identities of their local consultants. Other reports (e.g. Kameubun 2013; Muliyawan 2013) had employed artificial ethnic designations such as Marind Sendawi anim, which treats the Kanum, Marind, Marori, and Yei tribes as a homogenous study subject even though the four tribes have different languages. Similarly, Haryanto and colleagues (2009) used Marind terminology in their study of medicinal plants amongst ethnic tribes residing within the WNP area and mixed up plant names without specifying their linguistic origin as Marind, Marori, or Kanum. These two examples illustrate the difficulty of obtaining reliable data for further analysis from such reports.

Ethnobotanical research in Indonesia has been criticized by Rifai and Walujo (1992, references in Walujo 2011) for being simple systematic botanical studies and for focusing on plants with obvious economic value. Most ethnobotany reports in libraries of various universities in Indonesia contain only reports of economic value and descriptions of plants. Cognitive ethnobiological studies are urgently needed because of the unprecedented and accelerating loss of biodiversity along with the loss of traditional cultural practices and linguistic messages that provide communities with knowledge about ecological sustainability and natural resource management (Posey and Dutfield 1996). Such knowledge was formerly transmitted through oral narration, so much of it remains undocumented. 
For example, Walujo (2011) suggests that ethnobotany should encompass the study of how a society understands and perceives plants, in addition to using them, in the context of the human relationship with the environment. Perceptions and conceptions form two axes in ethnobotanical studies. Ethnobotany serves as a bridge to deepen perceptions and conceptions in relation to the vegetal resources of the environment. These terms relate more to cognition than to pure utilitarianism and suggest that cognitive ethnobiological studies amongst different ethnic groups in the region would be fruitful (Ross and Revilla-Minaya 2011). The cognitive approach has been somewhat illustrated in research by, Warib (1996), Muliyawan et al. (2013), Wattimena (2013), Sofyandy (2014), and Hisa et al. (2017), but only limited data was provided in these studies. Documenting perceptual knowledge of the natural environment and its components, as well as language and other cultural aspects of each community within the Marind language-culture area, should thus be undertaken as part of the biocultural conservation effort. Another fact is recent ethnobiological studies have all been conducted around Merauke city. For the concern to conservation, future research should expand northward and westward, where many places are undergoing rapid environmental change due to oil palm plantations and other agricultural industries (Wattimena 2013). Adopting a quantitative approach to analyze the distribution of ethnobiological knowledge within the varied communities studied would be especially important given the extreme and rapid changes in the environment of the Merauke District region.

We argue that a biocultural conservation approach can be a bridge to facilitate aspects that have not been noticed by previous ethnobiological studies particularly with regard to cognitive ethnobiology. The areas of cognitive ethnobiology may include the study of how knowledge is acquired, transmitted, and transformed across cultures and generations, loss of knowledge as well as behavioral studies related to resource management and conflict over resources (Ross and Revilla-Minaya 2011; De Vette 2012; Kansky and Knight 2014; Madden and McQuinn 2014; McCarter et al. 2014; Teel et al. 2014; Norrman 2015; De Pourcq et al. 2015; Baynham-Herd et al. 2018), this area also includes knowledge of folk taxonomy (Keil 2013; Poncet et al. 2015; Berlin 2014) which has not been the concern of ethnobiologists in Indonesia today. This folk taxonomy study emphasizes the exploration of the sematic aspects of the language of existing indigenous peoples to find out the conceptions of landscape elements from various perspectives of indigenous peoples' knowledge (Abraao et al. 2010; Hunn and Meilleur 2010; Johnson 2010; Johnson and Hunn 2010; Johnson and DavidsonHunt 2011). This needs to be a concern because biocultural conservation includes the diversity of life and all that is manifested-biology, culture including language (Maffi and Woodley 2010) and losing one of them can cause another loss (Harmon 1996; Pretty et al. 2009; Si 2011). The context of biocultural conservation is very appropriate in this area because it has lost one language, Men Ge (Sohn et al. 2009) and one other language, Marori is threatened with extinction because it has very few fluent speakers (Arka
2013).

Characteristics of ethnobiological research are currently in phase 5 where there is a need for increased networks of various disciplines to address the challenges of rapid ecological changes and political economy shifts (Wyndham et al. 2011; Wolverton 2013). This is confirmed by the study of ethnobiology studies in Southeast Asia by Hidayati et al. (2015) that ethnobiology is necessary through studies relating to biocultural and socio-ecological diversity. Biocultural is a parallel approach and many theoretical contributions to the development of science as well as practically for the benefit of humans and the natural environment are generated through this approach. The contribution of the biocultural approach not only saves cultures and languages but also plays a role in other aspects such as food security, biological diversity and ecosystem functions (Tauli-Corpuz 2009; McGregor et al. 2010; RosTonen 2012; Barthel et al. 2013; Boillat et al. 2013; Hong 2013; Gavin et al. 2015; Sujarwo et al. 2015; Barthel et al. 2017; Lemke and Delormier 2017; Morales et al. 2017; Moura et al. 2017; Danarto et al. 2019), human health (Worthman and Costello 2009); multi-sector development (Davidson-Hunt et al. 2012; McCarter et al. 2018; Sterling et al. 2017), including paying special attention to the sustainable economic empowerment of indigenous peoples affected by various policies (e.g. Xu et al. 2009; Abebe and Bongers 2012; Schure 2012; Mustafa and Hajdari 2014; Carr et al. 2016). By looking at the flexibility of the role of a biocultural approach, this approach can be used for more comprehensive ethnobiological research purposes through a forum involving researchers from many relevant disciplines. Through this forum is expected to produce an intellectual document of imperative studies of ethnobiology with international standards that scientifically provide direction study, conformity, and development of the methodology to produce research and publication high in quantity and quality from all aspects of ethnobiology as an interdisciplinary field.

\section{ACKNOWLEDGEMENTS}

The authors thank the Republic of Indonesia Ministry of Research, Technology and Higher Education for the BPPDN scholarship for the first author. The preparation and publication of this manuscript were funded by the University of Indonesia Final Assignment Grant in 2018, therefore the authors express their gratitude to the leadership of the Faculty of Mathematics and Natural Sciences and the University of Indonesia (Universitas Indonesia), Depok, Indonesia.

The authors are also thanks to following people for their scientific advice: Late Dr. Herwasono Soedjito and Prof. Purwanto at Lembaga Ilmu Pengetahuan Indonesia (Indonesian Institute of Sciences), Dr. Abinawanto, Late Dr. Susiani Purbaningsih, Dr. Ratna Yuniati, and Dr. Lutfiralda Sjahfirdi at University of Indonesia. The authors would like to thank Enago (www.enago.com) for the English language review in the section "Biocultural Diversity Conservation: A Brief Overview". 


\section{REFERENCES}

Abebe T, Bongers F. 2012. Land-use dynamics in enset-based agroforestry homegardens in Ethiopia. In: Arts B, Van Bommel S, Ros-Tonen S, Verschoor, G (eds) Forest-People Interfaces. Wageningen Academic Publisher, Wageningen.

Abraao MB, Shepard GH, Nelson BW, Baniwa JC, Andrello G, Yu DW 2010. Baniwa vegetation classification in the White-Sand Campinarana habitat of the Northwest Amazon. In Johnson LM, Hunn ES (eds) Landscape Ethnoecology. Concepts of Biotic and Physical Space. Berghahn Books, New York.

Adams WM. 2010. No land apart: Nature, culture, landscape. In: Pilgrim S, Pretty J (eds) Nature and Culture: Rebuilding Loss Connection. Earthscan Publication, London.

Agnoletti M. 2014. Rural landscape, nature conservation and culture: Some notes on research trends and management approaches from a (southern) European perspective. Landsc Urban Plan 126: 66-73. DOI: 10.1016/j.landurbplan.2014.02.012

Agnoletti M, Rotherham ID. 2015. Landscape and biocultural diversity. Biodivers Conserv 24: 3155-3165.

Agnoletti M, Tredici M, Santoro A. 2015. Biocultural diversity and landscape patterns in three historical rural areas of Morocco, Cuba and Italy. Biodivers Conserv 24: 3387-3404.

Albo X. 2018. Suma Qamaña or living well together: A contribution to biocultural conservation. In: Rozzi R, May Jr RH, Chapin III FS, Massardo F, Gavin MC, Klaver IJ, Pauchard A, Nuñez MA, Simberlo D (eds). 2018. From Biocultural Homogenization to Biocultural Conservation. Ecology \& Ethics Series 3. DOI: 10.1007/978-3-31999513-7_21

Albuquerque UP, Medeiros PM de. 2013. What is evolutionary ethnobiology? Ethnobiol Conserv 2: 6.

Albuquerque UP, Cunha LVFC, Lucena RFP, Alves RRN. 2014. Methods and Techniques in Ethnobiology and Ethnoecology. Humana Press, London.

Albuquerque UP, Medeiros PM de, Casas A. 2015. Evolutionary Ethnobiology. Springer International Publishing Switzerland (Springer Science+Business Media), Cham.

Anderson EN 2010. The Pursuit of Ecotopia: Lessons from Indigenous and Traditional Societies for The Human Ecology of Our Modern World. Praeger, Santa Barbara

Anderson EN. 2011. Ethnobiology: overview of a growing field. In: Anderson EN, Pearsall DM, Hunn ES, Turner NJ (eds) Ethnobiology. John and Wiley Sons, Inc., Hoboken-New Jersey.

Anderson EN, Pearsall DM, Hunn ES, Turner NJ. 2011. Ethnobiology. John and Wiley Sons, Inc., Hoboken-New Jersey.

Andrachuk M, Armitage D. 2015. Understanding social-ecological change and transformation through community perception of system identity. Ecol Soc 20 (4): 26. DOI: 10.5751/ES-07759-200426

Arka I. 2013. Language management and minority language maintenance in (eastern) Indonesia: strategic issues. Lang Document Conserv 7: 74-105.

Arts B, Van Bommel S, Ros-Tonen S, Verschoor G. 2012. Forest-people interfaces: from local creativity to global concerns. In: Arts B, Van Bommel S, Ros-Tonen S, Verschoor G (eds) Forest-People Interfaces. Wageningen Academic Publisher, Wageningen.

Barrau J, Scheffler HW. 1966. Cultivators in the swamps: Social structure and horticulture in a New Guinea society (Frederik-Hendrik Island West New Guinea). L. M. Serpenti. Am Anthropol. DOI: 10.1525/aa.1966.68.4.02a00300.

Barthel S, Crumley C, Svedin U. 2013. Bio-cultural refugiasafeguarding diversity of practices for food security and biodiversity. Global Environ Chang 23: 1142-1152.

Barthel S, Crumley CL, Svedin U. 2017. Biocultural refugia: combating the erosion of diversity in landscapes of food production. Ecol Soc 18 (4): 71 .

Baynham-Herd Z, Redpath S, Bunnefeld N, Molony T, Keane A. 2018 Conservation conflicts: behavioural threats, frames, and intervention recommendations. Biol Conserv 222: 180-188.

Bennett NJ, Roth R, Klain SC, Chan K, Christie P, Clark DA, ... Wyborn C. 2017. Conservation social science: Understanding and integrating human dimensions to improve conservation. Biol Conserv 205: $93-$ 108.

Bergamini N, Blasiak R, Eyzaguirre P, Ichikawa K, Mijatovic D, Nakao F, Subramanian SM. 2013. Indicator of Resilience in Socio-ecological
Production Landscapes (SEPLs). United Nations University, Yokohama.

Berlin B. 2014. Ethnobiological Classification: Principles of Categorisation of Plant and Animals in Traditional Societies. Princeton University Press, New Jersey.

Bogaert J, Franken I, Andre M. 2014. Anthropogenic effect in landscape: Historical context and spatial pattern. In: Hong SK, Bogaert J, Min Q (eds) Biocultural Landscape: Diversity, Function, and Value. Springer Science+Business Media, Dordrecht.

Boillat S, Mathez-Stiefel S, Rist S. 2013. Linking local knowledge, conservation practices and ecosystem diversity: comparing two communities in the Tunari National Park (Bolivia). Ethnobiol Conserv 2: 8. DOI: $10.15451 / \mathrm{ec} 2013-8-2.8-1-28$

Bremer LL, Falinski K, Ching C, Wada CA, Burnett KM, Kukea-Shultz K, Reppun N, Chun G, Oleson KLL, Ticktin T. 2018. Biocultural restoration of traditional agriculture: Cultural, environmental, and

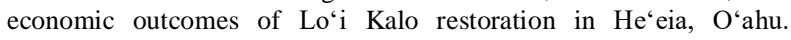
Sustainability 10: 4502. DOI: $10.3390 / \mathrm{su} 10124502$

Bridgewater P, Rotherham ID. 2019. A critical perspective on the concept of biocultural diversity and its emerging role in nature and heritage conservation. People Nat 1: 291-304.

Brosius JP, Hitchner SL. 2010. Cultural diversity and conservation. Int Soc Sci J 61 (199): 141-168. DOI: 10.1111/j.14682451.2010.01753.x

Brundu G, Peruzzi L, Domina G, Bartolucci F, Galasso G, Peccenini S, et al. 2017. At the intersection of cultural and natural heritage: Distribution and conservation of the type localities of Italian endemic vascular plants. Biol Conserv 214: 109-118.

Budiharta S, Meijaard E, Wells JA, Abram NK, Wilson KA. 2016. Enhancing feasibility: Incorporating a socio-ecological systems framework into restoration planning. Environ Sci Policy 64: 83-92.

Buizer M, Elands B, Vierikko K. 2016. Governing cities reflexively-The biocultural diversity concept as an alternative to ecosystem services. Environ Sci Policy 62: 7-13

Caillon S, Cullman G, Verschuuren B, Sterling EJ. 2017. Moving beyond the human-nature dichotomy through biocultural approaches: Including ecological well-being in resilience indicators. Ecol Soc 22 (4): 27. DOI: $10.5751 /$ ES-09746-220427

Carr A, Ruhanen L, Whitford M. 2016. Indigenous peoples and tourism: the challenges and opportunities for sustainable tourism. J Sustain Tour 24: 1067-1079.

Carroll J, Clasen M, Jonsson E, Kratschmer AR, McKerracher L, Riede F, Svenning JC, Kjærgaard PC. 2015. Biocultural theory: The current state of knowledge. Evol Behav Sci. DOI: 10.1037/ebs0000058

Clement D. 1998. The historical foundations of ethnobiology. J Ethnobiol 18 (2): $161-187$

Cocks M. 2010. What is biocultural diversity? A theoretical review. In: Bates DG, Tucker J (eds) Human Ecology-Contemporary Research and Practices. Springer Science+Business Media, New York.

Cocks ML, Dold T, Vetter S. 2012. 'God is my forest'-Xhosa cultural values provide untapped opportunities for conservation. S Afr J Sci $08(5 / 6): 1-8$.

Cocks ML, Wiersum F. 2014. Reappraising the concept of biocultural diversity: a perspective from South Africa. Hum Ecol 42: 727-737. DOI: $10.1007 / \mathrm{s} 10745-014-9681-5$

Convention on Biological Diversity (CBD). 2018. The Sharm El-Sheikh Declaration on Nature and Culture. www.cbd.int/doc/c/8b76/d85e/c62f9 20c5f d8c47 43e51 93e1/cop-14inf-46-en.pdf

Convention on Biological Diversity (CBD). 2019. Uses of Terms. www.cbd.int/convention/articles/default.shtml?a=cbd-02

Corbey R. 2010. Headhunters from the Swamps: The Marind Anim and New Guinea as Seen by the Missionaries of the Sacred Heart, 19051925. KTTLV Press, Leiden.

D'Ambrosio U. 2014. Theoretical reflections on ethnobiology in the third millenium. Contrib Sci. DOI: 10.2436/20.7010.01.188.

Danarto SA, Budiharta S, Fauziah F. 2019. Tree species preference and rehabilitation perspective by local community: Case study in Bondowoso, East Java, Indonesia. Asian J For 3 (2): 54-63.

Davidson-Hunt IJ, Turner KL, Mead ATP, Cabrera-Lopez J, Bolton R, Idrobo CJ, Miretski I, Morrison A, Robson JP. 2012. Biocultural design: a new conceptual framework for sustainable development in rural indigenous and local communities. SAPIENS 5 (2): 33-45.

De Pourcq K, Thomas E, Arts B, Vranckx A, Leon-Sincard T, Van Damme P. 2015. Conflict in protected areas: Who says co- 
Management does not work? PLOS One. DOI: 10.1371/journal.pone. 0144943

De Vette M. 2012. Conservancies in Namibia: a discourse in action. In: Arts B, Van Bommel S, Ros-Tonen S, Verschoor, G (eds) ForestPeople Interfaces. Wageningen Academic Publisher, Wageningen.

Díaz S, Demissew S, Carabias J, Joly C, Lonsdale M, Ash N, .. Zlatanova D. 2015. The IPBES conceptual framework-Connecting nature and people. Curr Opin Env Sust 14: 1-16.

Dudley N, Bhagwat S, Higgins-Zogib L, Lassen B, Verschuuren B, Wild R. 2010. Conservation of biodiversity in sacred natural sites in Asia and Africa: A review of the scientific literature. In: Verschuuren B, Wild R, McNeely J, Oviedo G (eds) Sacred Natural Sites: Conserving Nature and Culture. Earthscan, London.

Dunn CP. 2017. Biological and cultural diversity in the context of botanic garden conservation strategies. Plant Diver 39: 396-401.

Ekblom A, Shoemaker A, Gillson L, Lane P, Linholm K-J. 2019. Conservation through biocultural heritage-Examples from SubSaharan Africa. Land 8 (5). DOI: 10.3390/land8010005

Eriksson O. 2018. What is biological cultural heritage and why should we care about it? An example from Swedish rural landscapes and forests. Nat Conserv 28. DOI: 10.3897/natureconservation.28.25067

Franco JL de A. 2013. The concept of biodiversity and the history of conservation biology: from wilderness preservation to biodiversity conservation. Historia 32 (2): 21-48.

Frascaroli F, Verschuuren B. 2016. Linking biocultural diversity and sacred sites: Evidence and recommendations in the European framework. In: Agnoletti M, Emanueli F (eds) Biocultural Diversity in Europe, Environmental History 5. DOI: 10.1007/978-3-319-26315$1 \_21$

Gavin MC, McCarter J, Mead A, Berkes F, Step RJ, Peterson D, Tang R. 2015. Defining biocultural approaches to conservation. Trends Ecol Evol. DOI: 10.1016/j.tree.2014.12.005.

Gavin MC, McCarter J, Berkes F, Mead ATP, Sterling EJ, Tang R, Turner NJ. 2018. Effective biodiversity conservation requires dynamic pluralistic, partnership-based approaches. Sustainability 10, 1846; DOI: $10.3390 /$ su 10061846

Gonzales T, Gonzalz M. 2010. From colonial encounter to decolonizing encounters. Culture and nature seen from the Andean cosmovision of ever: The nurturance of life as whole. In: Pilgrim S, Pretty J (eds) Nature and Culture: Rebuilding Loss Connection. Earthscan Publication, London.

Gorenflo LJ, Romaine S, Mittermeier RA, Walker-Painemilla K. 2012. Co-occurrence of linguistic and biological diversity in biodiversity hotspots and high biodiversity wilderness areas. Proc Natl Acad Sci USA 109 (21): 8032-8037.

Grant C. 2012. Analogies and links between cultural and biological diversity. J Cult Heritage Manag Sustain Dev 2 (2): 153-163.

Gressit JL. 1982. Biogeography and Ecology of New Guinea. The Hague, Boston/London.

Gyampoh BA, Asante WA. 2011. Mapping and Documentation of Indigenous Knowledge in Climate Change Adaptation in Ghana. Africa Adaptation Programme (AAP) and United Nation Development Programme (UNDP), New York.

Harbelubun AE, Kesaulija EM, Rahawarin YY. 2005. Natural plant dyes and their traditional use by Marori-Men gey people in Wasur National Park, Merauke District. Biodiversitas 6 (4): 281-284. DOI: 10.13057/biodiv/d060414.

Hariadi BT. 2005. Procedure of planting and post-harvest handling of gembili (Dioscorea spp) by Kanum tribe in Wasur National Park Merauke: an ethnobotanical review. In: Karafir YP, Matanubun H, Soenarto, Abdullah Y, Nugroho B, Tokede MJ (eds) Proceeding of The National Workshop on Reform Specific Local Food. Collaboration of Department of Agriculture and Horticultural Jayapura, Papua State University and Government of Papua Province, Jayapura. [Indonesian]

Harmon D. 1996. Losing species, losing languages: Connecting between biological and linguistic diversity. Southwest J Linguist 15 (1-2): 89 109.

Harmon D, Loh J. 2010. The index of linguistic diversity: A new quantitative measure of trends in the status of the world's languages Language Documentation \& Conservation 4: 97-151.

Harmon D, Woodley E, Loh J. 2010. Measuring status and trends in biological and cultural diversity. In: Pilgrim S, Pretty J (eds) Nature and Culture: Rebuilding Loss Connection. Earthscan Publication, London.
Haryanto D, Tanjung RHR, Kameubun KMB. 2009. The use of medicinal plant by Marind people living in Wasur National Park, Merauke. J Biol Papua 1 (2): 58-64.

Hidayati S, Franco FM, Bussmann RW. 2015. Ready for phase 5-current status of ethnobiology in Southeast Asia. J Ethnobiol Ethnomed 11 (17). DOI: 10.1186/s13002-015-0005-7

Hide R. 2017. A preliminary bibliography of ethnobotanical research in West Papua (Indonesia), Part I: Publications 2000-2013 (Version 4, June 2014) Vol. 4. Supplement \#4 (September 2017).

Hill R, Cullen, Unsworth LC, Talbot LD, McIntyre, Tamwoy S. 2011. Empowering indigenous peoples' biocultural diversity through World Heritage cultural landscapes: A case study from the Australian humid tropical forests. Int J Herit Stud 17 (6): 571-591.

Hisa L, Mahuze A, Arka IW. 2017. The ethnobotanical-linguistic documentation of sago: a preliminary report from the Marori of Wasur National Park. Linguistik Indonesia 35 (2): 187-200. [Indonesian]

Hong SK. 2013. Biocultural diversity conservation for island and islanders: Necessity, goal and activity. J Mar Isl Cult 2: 102-106.

Hong SK, Maffi L, Oviedo G, Matsuda H, Kim JE. 2014. Development and vision in island biocultural diversity initiative. In: Hong S-K, Bogaert J, Min Q (eds) Biocultural Landscape: Diversity, Function, and Value. Springer Science+Business Media, Dordrecht.

Hong SK. 2014. Philosophy and background of biocultural landscapes. In: Hong SK, Bogaert J, Min Q (eds) Biocultural Landscape: Diversity, Function, and Value. Springer Science+Business Media, Dordrecht.

Hong SK, Won YT, Lee GA, Han ES, Cho MR, Park HY, Kim JE, Hatfield SC. 2018. Interdisciplinary convergence research design on island biocultural diversity-Case study in Wando-gun (County) Island region, South Korea. J Mar Isl Cult 7 (1). DOI: 10.21463/jmic.2018.07.1.02

Howard PL. 2010. Culture and agrobiodiversity: Understanding the links. In: Pilgrim S, Pretty J (eds) Nature and Culture: Rebuilding Loss Connection. Earthscan Publication, London.

Hunn E. 2007. Ethnobiology in four phases. J Ethnobiol 27 (1). DOI: 10.2993/0278-0771 (2007)27[1: EIFP]2.0.CO;2

Hunn ES, Meilleur BA. 2010. Toward a theory of landscape ethnoecological classification. In: Johnson LM, Hunn ES (eds) Landscape Ethnoecology. Concepts of Biotic and Physical Space. Berghahn Books, New York.

Johnson LM. 2010. Trail of Story, Traveller's Path: Reflection of Ethnoecology and Landscape. Athabasca University Press, Edmonton.

Johnson LM, Hunn ES. 2010. Introduction. In: Johnson LM, Hunn ES (eds.). Landscape Ethnoecology. Concepts of Biotic and Physical Space. Berghahn Books, New York.

Johnson LM, Davidson-Hunt I. 2011. Ethnoecology and landscapes. In: Anderson EN, Pearsall D, Hunn E, Turner NJ (eds.). Ethnobiology. John Wiley \& Sons, Inc, Hoboken, New Jersey.

Jupiter S. 2017. Culture, kastom and conservation in Melanesia: What happens when worldviews collide? Pac Conserv Biol 23 (2): 139-145. DOI: 10.1071/PC16031

Kameubun KMB. 2003. Botanical and ethnobotanical aspects of wati (Piper methysticum Forst) on Marind Ethnic in Merauke, Papua. Institut Pertanian Bogor, Bogor.

Kameubun KMB. 2013. Indigenous Knowledge, Morphological Variation and Genetic Diversity of Kava (Piper methysticum Forst.) in Merauke, Papua, Indonesia. [Dissertation]. George-AugustUniversity, Gottingen, Gottingen. [Germany]

Kansky R, Knight AT. 2014. Key factors driving attitudes towards large mammals in conflict with humans. Biol Conserv 179: 93-105.

Keil FC. 2013. Root of folk biology. Proc Natl Acad Sci USA 110 (40): $15857-15858$

Knauft BM. 1993. South Cost New Guinea Cultures: History, Comparison, Dialectic. Cambridge University Press, Victoria.

Kooijman S. 1960. A Papuan lunar calendar: the reckoning of moons and seasons by the Marind-anim of Netherlands New Guinea. Man. DOI: $10.2307 / 2797877$

Kosmaryandi N. 2012. Wasur National Park, management of conservation area in indigenous community land. Media Konservasi 17 (1): 6-15. [Indonesian]

Laird SA, Awung GL, Lysinge RJ, Ndive LE. 2011. The interweave of people and place: biocultural diversity in migrant and indigenous livelihoods around Mount Cameroon. Int Forest Rev 13 (3): 275-293. 
Lemke S, Delormier T. 2017. Indigenous Peoples' food systems, nutrition, and gender: Conceptual and methodological considerations. Matern Child Nut 13. DOI: $10.1111 / \mathrm{mcn} .12499$

Lepofsky D. 2009. The past, present, and future of traditional resource and environmental management. J Ethnobiol 29 (2): 161-166.

Leurs LN. 2010. Medicinal, Aromatic and Cosmetic (MAC) Plants for Community Health and Bio-cultural Diversity Conservation in Bali, Indonesia. Leiden University, Leiden. https: //openaccess.leidenuniv.n1/handle/1887/14562

Liu Y, Zhao G, Yu Z. 2014. Developing integrated methods for biological conservation and sustainable production in agricultural landscapes. In: Hong SK, Bogaert J, Min Q (eds) Biocultural Landscape: Diversity, Function, and Value. Springer Science+Business Media, Dordrecht.

Lobo IW. 2012. Inventory of Marind tribe medicinal plant in Aletep village, Okaba District, Merauke District. Novae Guinea 4 (2): 378 387.

Loh J, Harmon D. 2005. Global diversity index. Ecol Indic 5: 231-241.

Lousley C. 2012. E. O. Wilson's Biodiversity, commodity culture, and sentimental globalism. In: Martin G, Myncite D, Munster U (eds) Why Do We Value Diversity? Biocultural Diversity in a Global Context. RCC Perspectives 9. DOI: 10.5282/rcc/5599

Luyken R, Luyken-Koning FW. 1955. Nutritional state of the Marindanim tribe in South New Guinea. Documenta Med Geogr Trop 7 (4): 315-39.

Lyver PO'B, Wilmshurst JM, Wood JR, Jones CJ, Fromont M, Bellingham PJ, Stone C, Sheehan M, Moller H. 2015. Looking back for the future: Local knowledge and palaeoecology inform biocultural restoration of coastal ecosystems in New Zealand. Hum Ecol 43: 681695. DOI: 10.1007/s10745-015-9784-7

Lyver PO'B, Rurub J, Scottc N, Tylianakis JM, Arnold J, Malinen SK, Bataille CY, Herse MR, Jones CJ, Gormley AM, Peltzer DA, Taura Y, Timoti P, Stone C, Wilcox M, Moller H. 2018. Building biocultural approaches into Aotearoa-New Zealand's conservation future. J Roy Soc New Zeal. DOI: 10.1080/03036758.2018.1539405

Maffi L. 2001. On biocultural diversity: Linking language, knowledge and the environment. Smithsonian Institution Press, Washington, DC.

Maffi L. 2005. Linguistic, cultural, and biological diversity. Ann Rev Anthropol 34: 599-617.

Maffi L, Woodley E. 2010. Biocultural Diversity and Conservation: Global Source Book. MPG Books, London.

Makondo, CC, Thomas DSG. 2018. Climate change adaptation: Linking indigenous knowledge with western science for effective adaptation. Environ Sci Policy 88: 83-91. DOI: 10.1016/j.envsci.2018.06.014

Martin GJ. 2001. Ethnobiology and ethnoecology. Encyclopedia Biodivers 2: 609-621.

Mastretta-Yanes, Gasman FA, Burgeff C, Ramirez MC, Pinero D, Sarukhan J. 2018. An initiative for the sand use of genetic diversity of domesticated plants and their wild relatives. Front Plant Sci 9: 209. DOI: 10.3389/fpls.2018.00209

McCarter J, Gavin MC, Baereleo S, Love M. 2014. The challenges of maintaining indigenous ecological knowledge. Ecol Soc. DOI: 10.5751/ES-06741-190339.

McCarter J, Sterling EJ, Jupiter SD, Cullman GD, Albert A, Basi M, et al. 2018. Biocultural approaches to developing well-being indicators in Solomon Islands. Ecol Soc. DOI: 10.5751/ES-09867-230132

McGregor S, Lawson V, Christophersen P, Kennett R, Boyden J, Bayliss P, Liedloff A, McKiage B, Andersen AN. 2010. Indigenous wetland burning: Conserving natural and cultural resources in Australia's worlds heritage-listed Kakadu National Park. Hum Ecol 38: 721-729.

Madden F, McQuinn B. 2014. Conservation's blind spot: The case for conflict transformation in wildlife conservation. Biol Conserv 178: 97-106.

Menzies CR, Butler B. 2006. Introduction: Understanding ecological knowledge. In: Menzies CR (ed) Traditional Ecological Knowledge and Natural Resource Management. University of Nebraska Press, Lincoln.

Molnar Z, Gelleny K, Margoczi K, Biro M. 2015. Landscape ethnoecological knowledge base and management of ecosystem services in a Szekely-Hungarian pre-capitalistic village system (Transylvania, Romania). J Ethnobiol Ethnomed 11 (3). DOI 10.1186/1746-4269-11-3.

Morales E, Morales S, Ladio A. 2017. A biocultural approach to firewood scarcity in rural communities inhabiting arid environments in Patagonia (Argentina). Ethnobio Conserv 6: 12.

Morishige K, Andrade P, Pascua P, Steward K, Cadiz E, Kapono L, Chong U. 2018. Nā Kilo 'Āina: Visions of biocultural restoration through indigenous relationships between people and place. Sustainability 10: 3368. DOI: 10.3390/su10103368.

Moura JMB, Ferreira-Júnior WS, da Silva TS, Albuquerque UP. 2017. Landscapes preferences in the human species: insights for ethnobiology from evolutionary psychology. Ethnobiol Conserv 6: 10 .

Mukul SA, Rashid AZMM, Uddin MB. 2012. The role of spiritual beliefs in conserving wildlife species in religious shrines of Bangladesh. Biodiversity 13 (2): 108-114. DOI: 10.1080/14888386.2012.694596

Muliyawan MB, Basuni S, Kosmaryandi N. 2013. The traditional wisdom of protection and usage of the forest resources by Ethnic Kanume in Wasur National Park. Media Konservasi 18 (3): 142-51. [Indonesian]

Murray G, Agyare A. 2018. Religion and perceptions of community-based conservation in Ghana, West Africa. PLoS One 13 (4). DOI: 10.1371/journal.pone. 0195498

Mustafa B, Hajdari A. 2014. Medical ethnobotanical studies in Kosovo. In: Pieroni A, Quave CL (eds) Ethnobotany and Biocultural Diversities in the Balkans. Springer Science+Business Media New York

Negi CS. 2010. Traditional culture and biodiversity conservation: Examples from Uttarakhand, Central Himalaya. Mt Res Dev 30 (3): 259-265.

Newing H. 2010. Bridging the gap: Interdisciplinarity, biocultural diversity and conservation. In: Pilgrim S, Pretty J (eds) Nature and Culture: Rebuilding Loss Connection. Earthscan Publication, London.

Norman L. 2015. Opportunities for Increased Conflict Management-A Cross-Case Study at the Department of Policy Implementation at the Swedish Environmental Protection Agency, Stockholm.

Ormsby A. 2012. Cultural and conservation values of sacred forests in Ghana. In: Pungetti P, Oviedo G, Hooke D (eds) Sacred Species and Sites: Advances in Biocultural Conservation. Cambridge University Press, Cambridge

Paolisso M, Dery N. 2010. A cultural model assessment of oyster restoration alternatives for the Chesapeake Bay. Hum Organ 69 (2): 169-179.

Persic A, Martin G (eds). 2008. Links between Biological and Cultural Diversity. Report of International Workshop. UNESCO, Paris.

Plieninger T, Kohsaka R, Bieling C, Hashimoto S, Kamiyama C, Kizos T, Penker M, Kieninger P, Shaw BJ, Sioen GB, Yoshida Y, Saito S. 2018. Fostering biocultural diversity in landscapes through placebased food networks: a "solution scan" of European and Japanese models. Sustain Sci 13: 219-233.

Poe MR, Norman KC, Levin PS. 2014. Cultural dimensions of socioecological systems: Key connections and guiding principles for conservation in coastal environments. Conserv Lett 7: 166-175. DOI: 10.1111/conl.12068

Poncet A, Vogl CR, Weckerle CS. 2015. Folkbotanical classification: morphological, ecological and utilitarian characterization of plants in the Napf region, Switzerland. J Ethnobiol Ethnomed 11 (13): http: //www.ethnobiomed.com/content/11/1/13

Posey D, Dutfield G. 1996. Beyond Intellectual Property: Toward Traditional Resources Rights for Indigenous People and Local Communities. International Development Research Centre, Ottawa.

Powell JM. 1976. Ethnobotany. In: Paijmans K (ed) New Guinea Vegetation. Australia National University Press, Canberra.

Pretty J, Adams B, Berkes F, de Athayde SF, Dudley N, Hunn E, Maffi L, Milton K, Rapport D, Robbins P, Sterling E, Stolton S, Tsing A, Vintinner E, Pilgrim S. 2009. The intersections of biological diversity and cultural diversity: Towards integration. Conserv Soc 7 (2): 100112.

Rahu AA, Hidayat K, Ariyadi M, Hakim L. 2013. Ethnoecology of kaleka: Dayak's agroforestry in Kapuas, Central Kalimantan Indonesia. Res J Agricult For Sci 1 (8): 5-12.

Robson JP, Berkes F. 2010. Exploring some of the myths of land use change: Can rural to urban migration drive declines in biodiversity? Glob Environ Chang 21: 844-854. DOI: 10.1016/j.gloenvcha.2011.04.009

Ross N, Revilla-Minaya C. 2011. Cognitive studies in Ethnobiology: What can we learn about the mind as well as human-environmental interaction? In: Anderson EN, Pearsall DM, Hunn ES, Turner NJ (eds) Ethnobiology. John and Wiley Sons, Inc., Hoboken-New Jersey.

Ros-Tonen M. 2012. Non-timber forest product extraction as a productive bricolage process. In: Arts $\mathrm{B}$, Van Bommel S, Ros-Tonen S, Verschoor, G (eds) Forest-people Interfaces. Wageningen Academic Publisher, Wageningen. 
Rotherham ID. 2015. Bio-cultural heritage and biodiversity: emerging paradigms in conservation and planning. Biodivers Conserv 24: 34053429.

Rozzi R. 2018. Biocultural conservation and biocultural ethics. In: Rozzi R, May Jr RH, Chapin III FS, Massardo F, Gavin MC, Klaver IJ, Pauchard A, Nuñez MA, Simberlo D (eds) From Biocultural Homogenization to Biocultural Conservation. Ecol Ethics 3. DOI: 10.1007/978-3-319-99513-7_19

Santika T, Wilson KA, Budiharta S, Kusworo A, Meijaard E, Law EA, Friedman R, Hutabarat JA, Indrawan TP, St. John FAV, Struebig MJ 2019. Heterogeneous impacts of community forestry on forest conservation and poverty alleviation: Evidence from Indonesia. People Nat 1: 204-219.

Schure J. 2012. Woodfuel and producers' livelihoods in the Congo Basin In: Arts B, Van Bommel S, Ros-Tonen S, Verschoor, G (eds) ForestPeople Interfaces. Wageningen Academic Publisher, Wageningen.

Si A. 2011. Biology in language documentation. Lang Document Conserv 5: $169-186$.

Si A, Agnihotri S. 2014. Solega place names and their ecological significance. Anthropol Linguist 56 (3/4): 389-414.

Singh S, Youssouf M, Malik ZA, Bussmann RW. 2017. Sacred groves: Myths, beliefs, and biodiversity conservation-a case study from Western Himalaya, India. Int J Ecol. DOI: 10.1155/2017/3828609

Singh S, Bhat JA, Malik ZA, Youssouf M, Bussmann RW, Kunwar RM. 2019. Sacred groves in Western Himalaya, India: Communitymanaged nature refuges for conservation of biodiversity and culture. Ethnobot Res Appl 8: 15. DOI: 10.32859/era.18.15.1-21

Skutnabb-Kangas T, Harmon D. 2015. Biological diversity and language diversity: parallels and differences. In: Penz H, Fill A (eds) Handbook of Ecolinguistics. Routledge, New York.

Sofyandy D. 2014. Environmental wisdom of local communities Malind anim tribes in natural resources management at Merauke region Papua province. In: Lee SS, Mas'ud FA, Siregar CA, Pratiwi, Mindawati N, Pari G, Turjaman M, Krisdianto, Krisnawati H, Siregar IZ, Laba W, Mardiastuti A, Wahyudi I (eds) Proceeding of The Second International Conference of Indonesian Forestry Researchers (INAFOR). Indonesian Forestry Researchers, Jakarta. [Indonesian]

Sohn MS, Lebold R, Kriens R. 2009. Report on the Merauke Sub-District Survey, Papua, Indonesia. SIL. Www01.sil.org/silesr/2009/silesr2009-018.pdf

Stepp JR, Cervone S, Castaneda H, Lasseter A, Stocks S, Gichon Y. 2004. Development of a GIS for global biocultural diversity. Policy Matters 13: $267-270$.

Stepp JR, Castaneda H, Cervone S. 2005. Mountains and biocultural diversity. Mt Res Dev 25 (3): 223-227. DOI: 10.1659/0276-474 (2005)025[0223: MABD]2.0.CO;2

Sterling EJ, Gomez A, Porzecanski AL. 2010. A systemic view of biodiversity and its conservation: Processes, interrelationships, and human culture. Bioassay 32: 1090-1098.

Sterling EJ, Filardi C, Toomey A, Sigouin A, Betley E, Gazit N, et al. 2017. Biocultural approaches to well-being and sustainability indicators across scales. Nat Ecol Evol. DOI: 10.1038/s41559-0170349-6

Suharno, Tanjung RHR, Sufaati S, Agustini V. 2016. Wati (Piper methysticum) medicinal plant: the ethnobiological and ethnomedicinal values of the Marind tribe in Merauke, Papua, Indonesia. Biodiversitas 17 (2): 814-822. DOI: 10.13057/biodiv/d170259.

Sujarwo W, Arinasa IBK, Caneva G, Guarrera PM. 2015. Traditional knowledge of wild and semi-wild edible plants used in Bali (Indonesia) to maintain biological and cultural diversity. Plant Biosyst 150 (5): 971-976. DOI: 10.1080/11263504.2014.994577

Sukhdev P, Wittmer H, Miller D. 2014. The Economics of Ecosystems and Biodiversity (TEEB): Challenges and responses. In: Helm D, Hepburn C (eds), Nature in the Balance: The Economics of Biodiversity. Oxford University Press, Oxford.

Sulistyawan BS, Verweij PA, Boot RGA, Purwanti B, Rumbiak W, Wattimena MC, Rahawarin P, Adzan G. 2018. Integrating participatory GIS into spatial planning regulation: The case of Merauke District, Papua, Indonesia. Intl J Commons 12 (1): 26-59.

Susiarti S. 2005. The alternative choices of masticatory customs by local people in Wasur National Park, Merauke, Papua. Biodiversitas 6 (3): 217-219. DOI: 10.13057/biodiv/d060316.

Sutton MQ, Anderson EN. 2014. Introduction to Cultural Ecology (3 $3^{\text {rd }}$ edition). Altamira Press, Lanham.

Swiderska K. 2013. What is "biocultural heritage" and "biocultural innovation?" Landscape 2 (13). www.bioculturalheritage.org
Tauli-Corpuz V. 2009. The Importance of Indigenous Peoples in Biodiversity Conservation. Environment Matters 2009. The World Bank Group, New York

TEEB. 2010. The Economics of Ecosystems and Biodiversity: Ecological and Economic Foundations. In: Kumar P (ed.). Routledge, London.

Teel TL, Manfredo MJ, Jensen FS, Buijs AE, Fischer A, Riepe C, Arlinghaus R, Jacobs MH. 2014. Understanding the cognitive basis for human-wildlife relationships as a key to successful protected-area management. Int J Sociol 40 (3): 104-123.

Temudo MP, Figueira R, Abrantes M. 2014. Landscapes of bio-cultural diversity: shifting cultivation in Guinea-Bissau, West Africa. Agroforest Syst. DOI 10.1007/s10457-014-9752-z

Tyrrel M. 2010. Biodiversity and cultural diversity: The interdependent and the indistinguishable. In: Pilgrim S, Pretty J (eds) Nature and Culture: Rebuilding Loss Connection. Earthscan Publication, London.

Upadhyay RK, Hasnain SI. 2017. Linguistic diversity and biodiversity. Lingua 195: 110-123. DOI: 10.1016/j.lingua.2017.06.002

Van Baal J. 1966. Dema: Description and Analysis of Marind-Anim Culture (South New Guinea), with the Collaboration of Father J. Verschueren. The Hague, M. Nijhoff, Amsterdam.

Van Baal J. 1982. Jan Verschuerens Description of Yei-nan Culture. Extracted from the Posthumous Papers. The Hague, M. Nijhoff, Amsterdam.

Walujo EB. 2008. Research ethnobotany in Indonesia and the future $\begin{array}{llll}\text { perspectives. } & \text { Biodiversitas } 9 \text { (1): 59-63. DOI: }\end{array}$ 10.13057/biodiv/d090114.

Walujo EB. 2011. Ethnobotany contributes to the understanding human relationship with plant and their environment. J Biol Indones 7 (2): 375-391. [Indonesian]

Wambrauw EV. 2015. Water resource management in the lowlands of Southern Papua using a decision support system and integrating traditional ecological knowledge. [Dissertation]. University of Auckland, New Zealand. http: //researchspace.aucland.ac.nz

Warib M. 1996. Marind-Anim Tribe in Merauke District. In: Ethnography of Irian Jaya: Marind, Moi, Nafri, Meyakh, and Papua-Indonesian in the Year of 2000. Government of Irian Jaya Province, Jayapura.

Wattimena MC. 2013. Wisdom Perspective of Malind Tribe Important Sites as Referrals in Detailed Land Use Plan Preparation of Merauke District. Institut Pertanian Bogor, Bogor.

Widya YA. 2015. Bio-ecology, ethnobotany and conservation of ketimunan/Timonius timon (Spreng.) Merr. on local society of Kanume Tribe in Wasur National Park, Papua. Institut Pertanian Bogor, Bogor.

Wilson EO. 1988. Biodiversity. National Academy Press, Washington, DC.

Winara A. 2015. The use of medicinal plant by the Marind Tribe in Wasur National Park. Albisia 11 (2): 12-20.

Winara A, Suhaendah E. 2015. Ethnobotany of the Marori-Men Gey Tribe and the potential of the agroforestry in Wasur National Park, Papua. In: Rachmand E, Kusumawardana N, Widyaningsih TS, Kuswantoro DP (eds) Proceedings of National Seminar of Agroforestry. Agroforestry Research Center, Ciamis. [Indonesian]

Winara A, Mukhtar AS. 2016. Utilization of medicinal plants by Kanum tribe in Wasur National Park, Papua. Penelitian Hutan dan Konservasi Alam 13 (1): 57-72. [Indonesian]

Woldeamanuel T. 2012. Gum and resin-producing species in the drylands of Ethiopia: productive bricolage footprints on the landscape. In: Arts B, Van Bommel S, Ros-Tonen S, Verschoor G (eds) Forest-People Interfaces. Wageningen Academic Publisher, Wageningen.

Wolverton S. 2013. Ethnobiology 5: Interdisciplinarity in an era of rapid environmental change. Ethnobiol Lett. DOI: 10.14237/ebl.4.2013.2125 .

Worthman CM, Costello EJ. 2009. Tracking biocultural pathways to health disparities: The value of biomarkers. Ann Hum Biol. DOI: 10.1080/03014460902832934

Wyndham FS, Lepofsky D, Tiffany S. 2011. Taking stock in ethnobiology: where do we come from? What are we? Where are we going? J Ethnobiol 31 (1): 110-127.

Xu J, Lebel J, Sturgeon J. 2009. Functional links between biodiversity, livelihoods, and culture in a Hani swidden landscape in Southwest

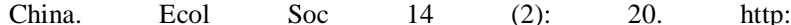
//www.ecologyandsociety.org/vol14/iss2/art20/

Yaofeng L, Jinlong L, Dahong Z. 2009. Role of traditional beliefs of Baima Tibetans in biodiversity conservation in China. Forest Ecol Manag 257: 1991-2001. DOI: 10.1016/j.foreco.2009.01.001 